\title{
Sensitivity Analysis of the Add-On Price Estimate for the Edge- Defined Film-Fed Growth Process
}

Anant R. Mokashi

Akaram $\mathrm{H}$. Kachare

March 15, 1981

Prepared for

U.S. Department of Energy

Through an agreement with

National Aeronautics and Space Administration

by

Jet Propulsion Laboratory

California Institute of Technology

Pasadena, California

(JPL PUBLICATION 81-37) 


\section{DISCLAIMER}

This report was prepared as an account of work sponsored by an agency of the United States Government. Neither the United States Government nor any agency Thereof, nor any of their employees, makes any warranty, express or implied, or assumes any legal liability or responsibility for the accuracy, completeness, or usefulness of any information, apparatus, product, or process disclosed, or represents that its use would not infringe privately owned rights. Reference herein to any specific commercial product, process, or service by trade name, trademark, manufacturer, or otherwise does not necessarily constitute or imply its endorsement, recommendation, or favoring by the United States Government or any agency thereof. The views and opinions of authors expressed herein do not necessarily state or reflect those of the United States Government or any agency thereof. 


\section{DISCLAIMER}

Portions of this document may be illegible in electronic image products. Images are produced from the best available original document. 


\section{Sensitivity Analysis of the Add-On Price Estimate for the Edge- Defined Film-Fed Growth Process}

Anant R. Mokashi

Akaram H. Kachare

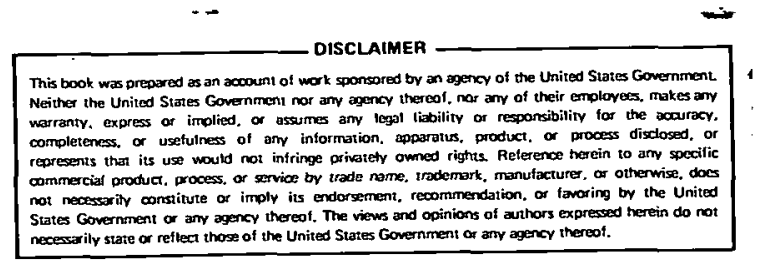

March 15, 1981

Prepared for

U.S. Department of Energy

Through an agreement with

National Aeronautics and Space Administration

by

Jet Propulsion Laboratory

California Institute of Technology

Pasadena, California

(JPL PUBLICATION 81-37) 
Prepared by the Jet Propulsion Laboratory, California Institute of Technology, for the Department of Energy through an agreement with the National Aeronautics and Space Administration.

The JPL Low-Cost Solar Array Project is sponsored by the Department of Energy (DOE) and forms part of the Photovoltaic Energy Systems Program to initiate a major effort toward the development of low-cost solar arrays.

This report was prepared as an account of work sponsored by the United States Government. Neither the United States nor the United States Department of Energy, nor any of their cmployccs, nor any of their contractors, subcontractors, or their employees, makes any warranty, express or implied, or assumes any legal liability or responsibility for the accuracy, completeness or usefulness of any information, apparatus, product or process disciosed, or represents that its use would not infringe privately owned rights. 
The edge-defined film-fed growth (EFG) process is a silicon-sheet technology option that is being developed for the Low-Cost Solar Array (LSA) Project, which is sponsored by the Department of Energy.

In order to achieve the LSA price goal of $\$ 0.70 / \mathrm{W}_{\mathrm{p}}$, certain required production-rate and sheet-quality standards must be met. One way to increase the production rate without seriously affecting the quality is to grow multiple ribbons simultaneously from a single machine.

This study presents a sensitivity analysis of the process add-on price in terms of cost parameters such as equipment, space, direct labor, materials and utilities, and the production parameters such as growth rate, process yield and duty cycle, using a computer program developed specifically to do the sensitivity analysis with IPEG. 
The authors thank K. M. Koliwad, M. H. Leipold and J. K. Liu of the Jet Propulsion Laboratory for reviewing the manuscript and offering suggestions for improvement, and F. Wald of Mobil Tyco Solar Energy Corp. for providing the base-case input data for the sensitivity analysis. 


\section{EXECUTIVE SUMMARY}

The Edge-defined Film-fed Growth (EFG) process is one of the siliconsheet technology options that is being developed by Mobil Tyco Solar Energy Corporation (MTSEC), for the Low-cost Solar Array (LSA) Project, sponsored by the Department of Energy. The add-on price goal for the EFG process is $\$ 23.30 / \mathrm{m}^{2}$ or $\$ 0.21 / \mathrm{W}_{\mathrm{p}}$ at an encapsulated cell efficiency of $12.0 \%$. This is consistent with the LSA Project price goal of $\$ 0.70 / \mathrm{W}_{\mathrm{p}}(1980 \$)$ for photovoltaic modules with efficiency of $11.4 \%$.

In order to achieve the goal, a certain production rate and sheet quality is required. One way to increase the production rate without seriously affecting the quality is to grow multiple ribbons simultaneously from a single machine. Present technology development efforts are directed toward growing four ribbons, each $10 \mathrm{~cm}$ wide, simultaneous $1 \mathrm{y}$ at a rate of 4.25 $\mathrm{cm} / \mathrm{min}$ from one machine. In the present Technology Readiness phase, MTSEC is designing and fabricating one machine to demonstrate these capabilities. The direct labor requirement is being assessed during this demonstration. Using the Interim Price Estimation Guideline (IPEG) procedure and projected input data provided by MTSEC, the calculated add-on price is $\$ 22.04 / \mathrm{m}^{2}(1980 \$)$, which is lower than the goal.

The present study performs a sensitivity analysis of the process add-on price in terms of cost parameters such as equipment, space, direct labor, materials and utilities, and the production parameters such as growth rate, process yield and duty cycle. The computer program developed specifically for doing the sensitivity analysis with IPEG is used in this study.

The breakdown of the add-on price of $\$ 22.04 / \mathrm{m}^{2}$ in terms of the cost parameters indicates that the primary cost driver is direct labor, which contributes $46 \%$ of the price with the assumption of three machines per operator (MPO). The sensitivity analysis shows that by varying the MPO from 1 to 6 the price is reduced from $\$ 42.22 / \mathrm{m}^{2}$ to $\$ 16.99 / \mathrm{m}^{2}$ and the corresponding direct-labor contribution is substantially reduced, from $72 \%$ to $30 \%$. By increasing the MPO to 9 , the price and labor contribution are reduced to $\$ 15.31 / \mathrm{m}^{2}$ and $22 \%$, respectively, which is of marginal benefit.

The EFG technology has been developed remarkably by MTSEC during the last five years. No serious technical problems are foreseen in meeting the Technical Readiness goal of $\$ 0.70 / \mathrm{W}_{\mathrm{p}}$. Several conceptual approaches exist to enhance this technology further, leading to a $\$ 0.50 / \mathrm{W}_{\mathrm{p}}$ level. Research and development efforts required for this demonstration should be initiated soon. 
THIS PAGE

\section{WAS INTENTIONALLY \\ LEFT BLANK}


CONTENTS

I. INTRODUCTION . . . . . . . . . . . . . . . . . . . . 1

II. SENSITIVITY ANALYSIS USING IPEG (SAIPEG) . . . . . . . . . . . . . . 3

A. PRICE ESTIMATION . . . . . . . . . . . . . . . . . 3

B. INPUT DATA . . . . . . . . . . . . . . . . . . 4

c. PRODUCTION ....................... . . 4

D. EQUIPMENT . . . . . . . . . . . . . . . . . . 7

E. AREA . . . . . . . . . . . . . . . . . 7

F. DIRECT LABOR ............... ...... 8

G. MATERIAL ...... . . . ......... : . 8

H. Utilities . . . . . . . . . . . . . . . . . 10

III. SENSITIVITY ANALYSIS . . . . . . . . . . . . . . . . . 13

A. PRODUCTION RATE ...................... . . 13

B. EQUIPMENT ....................... 13

c. ARea, Material, ANd Utilities. . . . . . . . . . . . 13

D. DIRECT LABOR. . . . . . . . . . . . . . . . 13

IV. SAIPEG RESULTS FOR THE EFG PROCESS . . . . . . . . . . . . . . 15

A. PRODUCTION RATE . . . . . . . . . . . . . . . . 15

B. COST OF EQUIPMENT ...................... 21

C. AREA, MATERIALS AND UTILITIES costs . . . . . . . . . . 21

D. DIRECT LABOR COST . . . . . . . . . . . . . 26

V. CONCLUSIONS . . . . . . . . . . . . . . . . . . . . . 29

REFERENCES .............................. 31 


\section{Figures}

1a. EFG Process Growth Rate vs Add-on Price for Duty

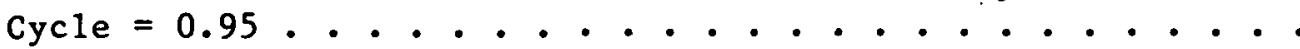

1b. EFG Process Growth Rate vs Add-on Price for Duty

Cycle $=0.90$. . . . . . . . . . . . . . . . . .

1c. EFG Process Growth Rate vs Add-on Price for Duty

Cycle $=0.85$. . . . . . . . . . . . . . . . . .

1d. EFG Process Growth Rate vs Add-on Price for Duty

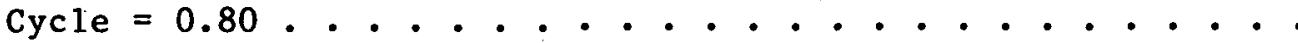

1e. EFG Process Growth Rate vs Add-on Price for Duty

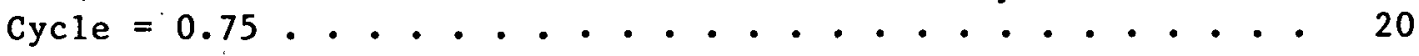

2. EFG Process Equipment Cost vs Add-on Price . . . . . . . . . 22

3. EFG Process Equipment Area vs Add-on Price . . . . . . . 23

4. EFG Process Direct Material Cost vs Add-on Price . . . . . . 24

5. EFG Process Utilities Cost vs Add-on Price . . . . . . . . 25

6. EFG Process Direct Labor Cost vs Add-on Price . . . . . . . 27

Tables

1. Base-Case Input Data for the Add-on Price Estimation Using SAIPEG ....................... 5

2. Price Estimation Results Using Base-Case Data . . . . . . . 11 


\title{
SECTION I
}

\author{
INTRODUCTION
}

The Low-Cost Solar Array (LSA) project, sponsored by the Department of Energy, has responsibility for developing photovoltaic solar array technology to make it technically feasible and commercially viable. The project goals are to achieve Technical Readiness for producing photovoltaic modules at the price of $\$ 0.70 / \mathrm{W}_{\mathrm{p}}$ by 1982 , and to achieve commercial readiness by 1986 . (Al1 monetary figures in this document are in 1980 dollars.)

Developing the technology for manufacturing large-area silicon sheets is one of the tasks in the Technology Development Area of the LSA Project. Several sheet-growth technologies are being developed in parallel under this task; the edge-defined film-fed growth (EFG) process, is one of them. The Mobil Tyco Solar Energy Corporation (MTSEC) has been working on EFG process development for the LSA Project since 1974.

The EFG process is described briefly thus: Polycrystalline silicon, as pellets or in similar form, is fed into a graphite crucible and is melted by heating the crucible in a furnace. The molten silicon is drawn out, in the form of a thin ribbon, through a wetted die under controlled thermal conditions. The width and thickness of the ribbon are determined by the configuration of the die.

Furnace and control designs are continuously being modified and improved, with the goal of achieving greater production with a reduction in cost of capital equipment, direct labor, area, materials, and utilities.

Melt replenishment has been developed, resulting in increased crucible life and longer growth runs. Similarly, multiple-ribbon growth has been successfully demonstratèd. Increasing the number of ribbons pulled simultaneously from the same crucible results in an increase in production rate per machine, with moderate increase in equipment outlay.

Much attention has been given to automating the process to minimize the direct labor requirement. It will be shown below that direct labor is EFG's primary cost driver, contributing $46 \%$ of the add-on price of the process.

According to the Price Allocation Guidelines (Reference 1), the add-on price goal for the EFG process is $\$ 23.3 / \mathrm{m}^{2}$. At the present level of demonstrated technology, the price estimate is much higher $\left(\$ 150 / \mathrm{m}^{2}\right)$ than the goal.*

A detailed cost analysis (Reference 2) was done by MTSEC in 1977. That analysis assumes a machine growing five ribbons, each $7.5 \mathrm{~cm}$ wide, at a rate of $7.5 \mathrm{~cm} / \mathrm{min}$. Experience has shown that it is difficult to achieve a growth rate of $7.5 \mathrm{~cm} / \mathrm{min}$ for simultaneous ribbon growth. Present plans are to

*Four-inch round $\mathrm{Cz}$ wafers cost about $\$ 3$ apiece, or about $\$ 370 / \mathrm{m}^{2}$ at today's prices. 
develop a machine that will grow four ribbons simultaneously, each $10 \mathrm{~cm}$ wide, at approximately $4.25 \mathrm{~cm} / \mathrm{min}$. The results of the 1977 analysis are updated and revised below.

It is desirable to perform a sensitivity analysis of the estimated price for the presently planned machine in terms. of production rate and cost parameters. The add-on price for the process is estimated using a version of the Interim Price Estimation Guidelines (IPEG) procedure (Reference 3). SAIPEG, a computer program especially developed to perform the sensitivity analysis, using IPEG, is used in this study. The results will aid in identifying the primary cost drivers and the sensitivity range of variations in the important parameters. This information will help in setting the direction of future technology development efforts. 
The add-on price of any standard assembly-line process is estimated by using the SAMICS (Reference 4) procedure and the SAMIS (Reference 5) program developed by JPL. The computer cost of using SAMIS is on the order of $\$ 100$ per run. The use of SAMICS/SAMIS procedure for doing a sensitivity analysis of a process involving large numbers of runs is therefore prohibitively expensive. The price estimation using the IPEG procedure is considered to be of sufficient accuracy to do the sensitivity analysis.

SAIPEG is a computer program (written in FORTRAN) for doing the sensitivity analysis using IPEG; the SAIPEG procedure is described below.

\section{A. PRICE ESTIMATION}

The IPEG 2 (improved version of IPEG, Reference 6) equation used in the current study is:

$$
\mathrm{AMC}=\mathrm{C} 1 \times \mathrm{EQPT}+\mathrm{C} 2 \times \mathrm{AREA}+\mathrm{C} 3 \times \mathrm{DLAB}+\mathrm{C} 4 \times(\text { TMATS + UTIL })
$$

where

\begin{tabular}{|c|c|c|}
\hline AMC & - & $\begin{array}{l}\text { Annual Manufacturing Cost }\left(\$ / y_{r}\right) \text {. (Required annual } \\
\text { revenue and AMC are used interchangeably.) }\end{array}$ \\
\hline EQPT & - & Total installed cost of the equipment $(\$)$ \\
\hline AREA & - & $\begin{array}{l}\text { Area required by the process equipment and its } \\
\text { operators for the production unit }\left(\mathrm{ft}^{2}\right) \text {. }\end{array}$ \\
\hline DLAB & - & Annual cost of direct labor $(\$ / y r)$. \\
\hline TMATS & - & Annual cost of materials and supplies $(\$ / y r)$ : \\
\hline UTIL & - & Annual cost of utilities $(\$ / y r)$. \\
\hline $\mathrm{Cl}$ & - & $\begin{array}{l}\text { The coefficient corresponding to EQPT, a function of } \\
\text { the Equipment Lifetime (ELT). ELT is assumed in this } \\
\text { study to be the same for al1 equipment. } \\
\begin{aligned} \mathrm{C} 1=0.83 \text { for ELT of } 3 \text { years, } \\
=0.65 \text { for ELT of } 5 \text { years, } \\
=0.57 \text { for ELT of } 7 \text { years, } \\
=0.52 \text { for ELT of } 10 \text { years, } \\
=0.48 \text { for ELT of } 15 \text { years, and } \\
=0.46 \text { for ELT of } 20 \text { years. }\end{aligned}\end{array}$ \\
\hline
\end{tabular}


C2 - The coefficient corresponding to AREA ( $\left.\$ / \mathrm{ft}^{2} / \mathrm{yr}\right)$.

$$
\mathrm{C} 2=109.0
$$

C3 - The coefficient corresponding to DLAB, varying with labor pay rates used in computing DLAB. (including fringe benefits, or not):

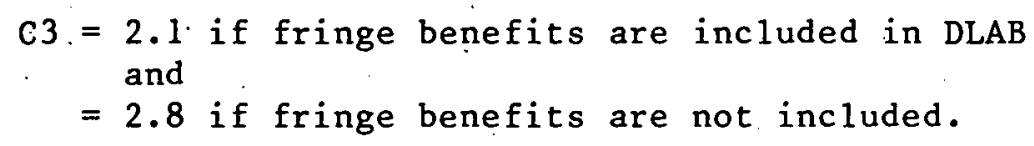
and$$
=2.8 \text { if fringe benefits are not included. }
$$

C4 - The coefficient corresponding to TMATS and UTIL.

$$
\mathrm{C} 4=1.2 \text {. }
$$

EQPT, AREA, DLAB, MATS and UTIL are referred to as cost parameters. The add-on price is estimated as follows:

$$
\operatorname{PRICE}\left(\$ / \mathrm{m}^{2}\right) \stackrel{=}{=} \operatorname{AMC}(\$) / Q T Y P Y R\left(\mathrm{~m}^{2}\right)
$$

where

QTYPYR $=$ The quantity of sheet produced per year $\left(\mathrm{m}^{2} / \mathrm{yr}\right)$.

\section{B. INPUT DATA}

The cost parameters and the quantity produced per year are in turn computed using the basic data for the process as described below. The input data for the example considered are given in Table 1.

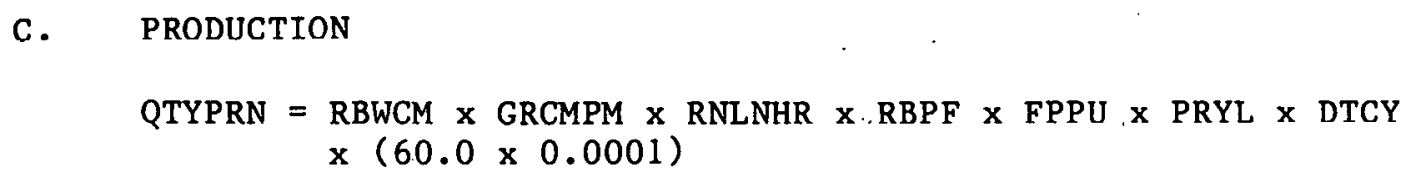

and

$$
\text { QTYPYR = QTYPRN } \times \text { RNPYR }
$$


Table 1. Base-Case Input Data for the Add-On Price Estimation Using SAIPEG

Ribbon width $(\mathrm{cm})$

PRODUCTION

,

Growth rate $(\mathrm{cm} / \mathrm{min})$

(RBWCM)

10.00

Run length (h)

(GRCMPM)

4.25

(RNLNHR)

160.00

Number of ribbons per furnace

(RBPF)

4.00

Number of furnaces per production unit

(FPPU)

1.00

Process yield

(PRYL)

0.90

Duty cycle

(DTCY)

0.90

Number of runs per year

(RNPYR)

48.00

\section{EQUIPMENT}

Furnace ( $\$ /$ each) (based on purchase of 100)

(FRNC)

$20,000.00$

Cartridge ( $\$ /$ ribbon)

(CRTG)

$5,000.00$

Melt replenishment equipment ( $\$ /$ furnace)

(EQMLRP)

$3,000.00$

Electro-optical controls ( $\$ /$ ribbon)

(EOC)

$2,000.00$

Equipment lifetime ( $y r$ )

(ELT)

7.00

$\underline{\text { AREA }}$

Area for one furnace unit $\left(\mathrm{ft}^{2}\right)$

(ARPF)

200.00

\section{DIREC'I' LAEOR}

Fringe benefits included

(FRBNIN)

No

Labor pay rate $(\$ / h)$

(PRTLB)

7.00

Number of furnaces per operator

(FPO)

3.00 
Table 1. Base-Case Input Data for the Add-On Price

Estimation Using SAIPEG (Cont.)

\section{MATERIALS}

Furnace insulation ( $\$ /$ furnace)

(FRINS)

$1,000.00$

Heating elements ( $\$ /$ furnace)

(HTEL)

200.00

Crucible ( $\$ /$ furnace)

(CRCBL)

75.00

Melt replenishment materials ( $\$ /$ furnace/run)

(RPML)

10.00

Die ( $\$ /$ ribbon)

(DIE)

2.00

Cartridge materials ( $\$ / \mathrm{ribbon} / \mathrm{run}$ )

(CRTMTL)

10.00

Furnace argon flow rate $\left(\mathrm{ft}^{3} / \mathrm{h} /\right.$ furnace)

(FAFR)

1.00

Cartridge argon flow rate $\left(\mathrm{ft}^{3} / \mathrm{h} / \mathrm{ribbon}\right)$

(CAFR)

0.50

Argon rate $\left(\$ / 100 \mathrm{ft}^{3}\right)$

(ARGPR)

3.20

Insulation 1 ifetime (runs)

(FINSLT)

48.00

Heating elements lifetime (runs)

(HTELLT)

48.00

Crucible lifetime (runs)

(CRLT)

48.00

Die lifetime (runs)

(DIELT)

1.00

\section{UTILITIES}

Furnacc power consumption ( $\mathrm{kW} /$ furnace)

(FURPC)

20.00

Cartridge and MR power consumption ( $\mathrm{kW} / \mathrm{ribbon}$ )

(CAMPRC)

1.50

Electricity power rate $(\$ / k W h)$

(EPRT)

0.08 
where

QTYPRN $\quad \begin{aligned} & \text { Quantity of silicon sheet produced per run. }(60.0 \times \\ & 0.0001) \text { is the conversion factor for converting } \\ & \mathrm{cm}^{2} / \mathrm{min} \text { to } \mathrm{m}^{2} / \mathrm{h} .\end{aligned}$
RNPYR
RBWCM

D. EQUIPMENT

$\mathrm{EQPT}=($ FRNC + EQMLRP + (CRTG + EOC $) \times \mathrm{RBPF}) \times \mathrm{FPPU}$

where

$\begin{array}{lll}\text { FRNC } & - & \text { Furnace cost }(\$ / \text { furnace }) . \\ \text { EQMLRP } & - & \text { Melt Replenishment Equipment }(\$ / \text { furnace }) . \\ \text { CRTG } & - & \text { Cartridge }(\$ / \text { ribbon }) . \\ \text { EOC } & - & \text { Electro-optical controls }(\$ / \text { ribbon). }\end{array}$

E. AREA

AREA $=$ ARPF $\times$ FPPU

where

ARPF

- The area required for each process equipment unit and
its operators ( $f t 2 /$ furnace) 
F. DIRECT LABOR

$\mathrm{OPPU}=\mathrm{FPPU} / \mathrm{FPO}$

DLAB $=4.7 \times$ OPPU $\times$ PRTLB $\times 40 \times 52.142$

where

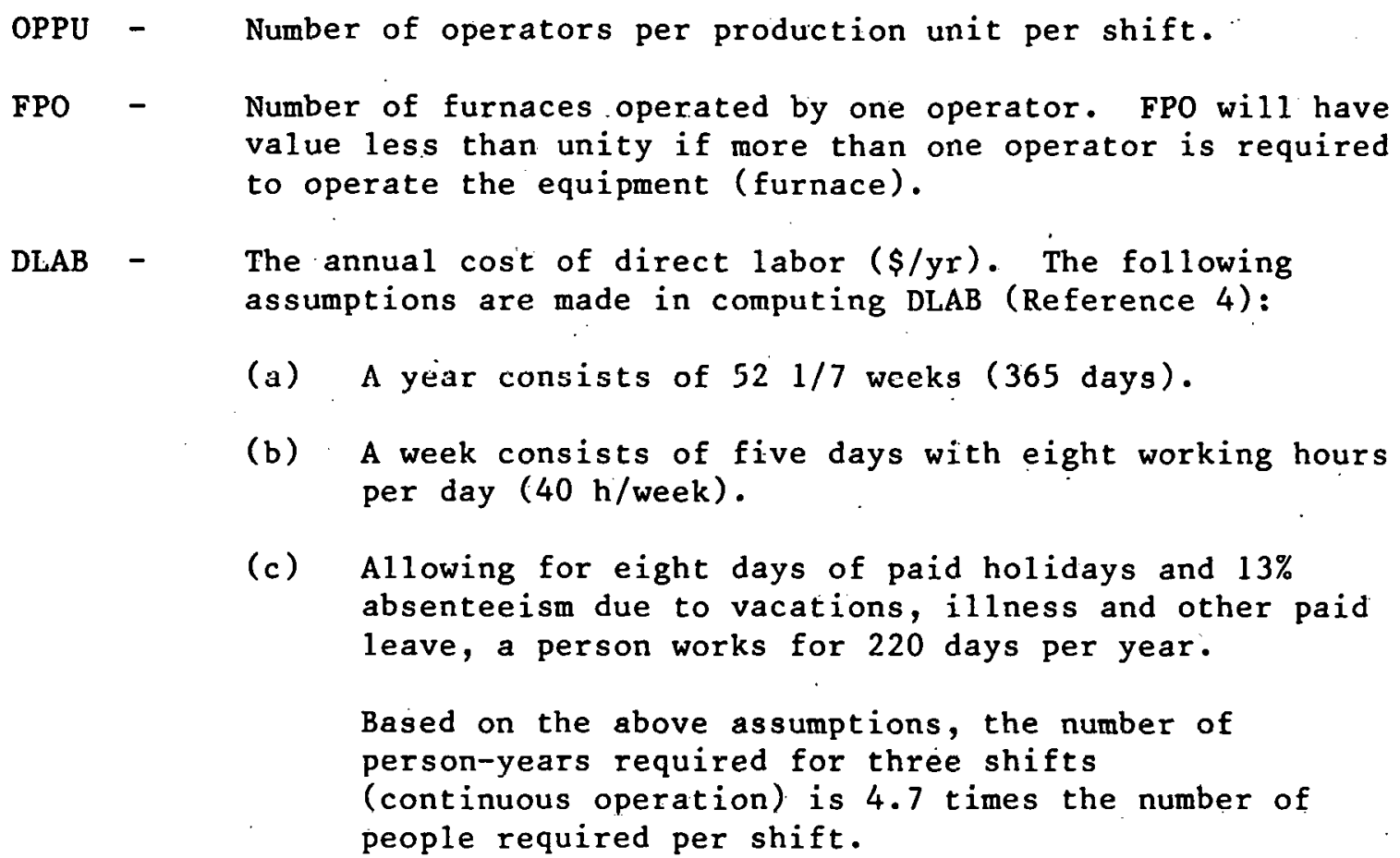

(a) A year consists of $521 / 7$ weeks (365 days).

(b) A week consists of five days with eight working hours per day $(40 \mathrm{~h} /$ week $)$.

(c) Allowing for eight days of paid holidays and 13\% absenteeism due to vacations, illness and other paid leave, a person works for 220 days per year.

Based on the above assumptions, the number of person-years required for three shifts

(continuous operation) is 4.7 times the number of people required per shift.

PRTLB - Labor Pay Rate $(\$ / \mathrm{h})$. It should be specified whether or not the PRTLB includes fringe benefits to determine the appropriate cuefficient to be used in couputing AMC.

G. MATERIAL

$$
\begin{aligned}
& \text { FINSYR }=(\text { FRINS } \times \text { RNPYR } \times \text { FPPU }) / \text { FINSLT } \\
& \text { HTELYR }=(\text { HTEL } \times \text { RNPYR } \times \text { FPPU }) / \text { HTELLT } \\
& \text { CRBLYR }=(\text { CRCBL } \times \text { RNPYR } \times \text { FPPU }) / \text { CRLT } \\
& \text { DIEYR }=(\text { DIE } \times \text { RNPYR } \times \text { RBPF } \times \text { FPPU }) / \text { DIELT } \\
& \text { CRMTYR }=(\text { CRTMTL } \times \text { RNPYR } \times \text { RBPF } \times \text { FPPU }) \\
& \text { RPMTYR }=(\text { RPML } \times \text { RNPYR } \times \text { FPPU })
\end{aligned}
$$




$$
\begin{aligned}
\text { FAY }= & (\text { ARGPR/100) } \times \text { FAFR } \times \text { WHPY } \times \text { FPPU } \\
\text { CAY }= & (\text { ARGPR/100) } \times \text { CAFR } \times \text { WHPY } \times \text { FPPU } \times \text { XRBPF } \\
\text { TMATS }= & \text { FINSYR + HTELYR + CRBLYR + DIEYR + CRMTYR + RPMTYR } \\
& + \text { FAY + CAY }
\end{aligned}
$$

\begin{tabular}{|c|c|c|}
\hline FINSYR & - & Cost of furnace insulation required $(\$ / y r)$. \\
\hline FRINS & - & Cost of furnace insulation ( $\$$ /furnace). \\
\hline FINSLT & - & Furnace insulation lifetime (runs). \\
\hline HTELYR & - & Cost of heating elements required $(\$ / y r)$. \\
\hline HTEL & - & Cost of heating elements ( $\$$ /furnace). \\
\hline HTELLT & - & Heating elements lifetime (runs). \\
\hline CRBLYR & - & Cost of crucibles required $(\$ / y r)$. \\
\hline CRCBL & - & Cost of crucibles ( $\$ /$ furnace). \\
\hline CRLT & - & Crucible lifetime (runs). \\
\hline DIEYR & - & Cost of dies required $(\$ / y r)$ \\
\hline DIE & - & Cost of dies ( $\$ /$ ribbon). \\
\hline DIELT & - & Die lifetime (runs). \\
\hline CRMTYR & - & Cost of cartridge materials $(\$ / y r)$. \\
\hline CRTMTL & - & Cost of cartridge materials ( $\$ /$ ribbon/run). \\
\hline RPMTYR & - & Cost of melt replenishment materials $(\$ / y r)$. \\
\hline RPML & - & Cost of melt replenishment materials ( $\$ /$ furnace/run). \\
\hline FAY & - & Cost of furnace argon $(\$ / y r)$ \\
\hline ARGPR & - & Cost of argon $\left(\$ / 100 \mathrm{ft}^{3}\right)$ \\
\hline FAFR & - & Furnace argon flow rate $\left(\mathrm{ft}^{3} / \mathrm{h} /\right.$ furnace). \\
\hline WHPY & - & $\begin{array}{l}\text { Working hours per year of the furnace. WHPY is the } \\
\text { product of run length in hours (RNLNHR) and the number } \\
\text { of runs per year (RNPYR). }\end{array}$ \\
\hline CAY & - & Cost of cartridge argon $(\$ / y r)$. \\
\hline CAFR & - & Cartridge argon flow rate $\left(\mathrm{ft}^{3} / \mathrm{h} /\right.$ furnace $)$. \\
\hline
\end{tabular}

where 
H. UTILITIES

$$
\begin{aligned}
& \text { FRPWYR }=\text { EPRT } \times \text { FURPC } \times \text { WHPY } \times \text { FPPU } \\
& \text { CAMPYR }=\text { EPRT } \times \text { CAMPRC } \times \text { WMPY } \times \text { FPPU } \times \text { RBPF } \\
& \text { UTIL }=\text { FRPWYR + CAMPYR }
\end{aligned}
$$

where

$\begin{array}{lll}\text { FRPWYR } & - & \text { Cost of furnace power consumption }(\$ / \mathrm{yr}) . \\ \text { EPRT } & - & \text { Electric power price }(\$ / \mathrm{kWh}) . \\ \text { FURPC } & - & \text { Furnace power consumption }(\mathrm{kW} / \text { furnace }) . \\ \text { CAMPYR } & - & \begin{array}{l}\text { Cost of cartridge and melt replenishment power } \\ \text { consumption }(\$ / \mathrm{yr}) .\end{array} \\ \text { CAMPRC } & -\quad \begin{array}{l}\text { Cartridge and melt replenishment power consumption } \\ (\mathrm{kW} / \mathrm{ribbon}) .\end{array}\end{array}$

Equations (3) to (20) provide the information required for computing the AMC and the production rate, which in turn are used in Equation (2) for price estimation. The results for the base-case data are presented in Table 2. The breakdown of the estimated price in terms of contributions from each cost parameter and also in percentage is given in Table 2. The SAIPEG program can be used to compute the price with different sets of input data. The sensitivity analysis capability of the SAIPEG program is described beluw. 
Table 2. Price Estimation Results Using Base-Case Data*

\section{PRODUCTION RATE}

Production quantity per run $\left(\mathrm{m}^{2}\right)$

132.192

Production quantity per year $\left(\mathrm{m}^{2}\right)$

$6,345.216$

\section{COST PARAMETERS AND COEFFICIENTS}

Parameter
Equipment $(\$)$
Area $\left(\mathrm{ft}^{2}\right)$
Direct labor (\$)
Materials $(\$) * *$
Utilities $(\$)$

Quantity

51,000

Coefficient

$C 1=0.57$

$\mathrm{C} 2=109.00$

200

$\mathrm{C} 3=2.80$

22,872

$\mathrm{C} 4=1.20$

4,796

$\mathrm{C5}=\mathrm{C4}$

REQUIRED ANNUAL REVENUE

Annual manufacturing costs (AMC) $(\$ / y r) \quad 139,839.09$

\section{ADD-ON PRICE ESTIMATE AND ITS BREAKDOWN}

\begin{tabular}{lrr} 
Parameter & $\frac{\$ / \mathrm{m}^{2}}{4.581}$ & \multicolumn{1}{c}{} \\
\cline { 2 - 2 } & 4.788 \\
Area & 3.436 & 15.589 \\
Direct Labor & 10.093 & 45.799 \\
Materials & 0.907 & 4.116 \\
Utilities & $\underline{3.021}$ & 13.708 \\
Total Price & 22.039 & 100.000
\end{tabular}

* The base-case data refer to a machine growing four ribbons simultaneously, each $10 \mathrm{~cm}$ wide, at a rate of $4.25 \mathrm{~cm} / \mathrm{min}$. It is assumed that three such machines are operated by one person.

$* *$ Excluding silicon 


\section{THIS PAGE WAS INTENTIONALLY LEFT BLANK}

12 
The SAIPEG program can perform a sensitivity analysis of the process add-on price as a function of the production rate or of any of the cost parameters within a specified range with known increments. The sensitivity analysis is performed with respect either to the production rate or to any of the cost parameters, varied one at a time with the rest of the data held constant. The production rate and the cost parameters in turn are varied by changing some of the basic input parameters, as described below.

\section{A. PRODUCTION RATE}

The production rate is varied for the $10-\mathrm{cm}$-wide ribbon by changing any of the three basic parameters: (a) duty cycle (DTCY), (b) process yield (PRYL), and (c) growth rate (GRCMPM). For the fixed value of DTCY and PRYL, the growth rate is changed from a specified minimum value to a specified maximum value with a desired increment. For each value of the GRCMPM, the add-on price is computed and GRCMPM vs add-on price is plotted. The procedure is repeated for each combination of DTCY and PRYL specified. The results for the example studied are discussed below.

\section{B. EQUIPMENT}

The contribution of equipment to AMC is calculated by varying (a) equipment lifetime and (b) equipment cost. For a given lifetime of equipment, the equipment cost (EQPT) is varied from a minimum value to a maximum value with specified increments. For each value of equipment cost the add-on price is estimated and the graph of equipment cost vs add-on price is plotted. The procedure is repeated for all of the values of equipment life of interest.

\section{AREA, MATERIAL, AND UTILITIES}

For each of these cost parameters the corresponding contributions to AMC are varied from minimum to maximum values with specified increments. The add-on price is estimated for each value of a parameter and parameter vs add-on price is plotted. Sensitivity analysis is performed with respect to one parameter at a time.

\section{J. DIRECT LABOR}

The contribution of DLAB to AMC is varied by changing two of the basic input parameters: (a) labor pay rate (PRTLB), and (b) the number of furnaces operated per operator (FPO). For a specified PRTLB, FPO is varied from a minimum to the specified maximum with desired increments. For each value of FPO, add-on price is computed and FPO vs add-on price is plotted. The procedure is repeated for each value of PRTLB of interest. 
It may be noted that the sensitivity analysis with respect to any of the cost parameters can be repeated for each value of the DTCY and PRYL and their specific combination of interest. Data and the results are discussed in the next section. 


\section{SECTION IV \\ SAIPEG RESULTS FOR THE EFG PROCESS}

Data for the economic analysis of the EFG process are being generated and continuously updated, based on technology development experience. MTSEC has demonstrated simultaneous pulling of five ribbons, each $5: \mathrm{cm}$ wide, at the rate of $2.5 \mathrm{~cm} / \mathrm{min}$ for 8 hours. The melt-replenishment technique has been introduced in the design of the ribbon growth machine. Based on experience, possible Technical Readiness developments have been projected. It has been demonstrated that ribbons $10 \mathrm{~cm}$ wide can be grown and that a ribbon can be grown at speeds greater than $4 \mathrm{~cm} / \mathrm{min}$. A machine capable of continuous operation is under development to achieve simultaneous growth of four ribbons, each $10 \mathrm{~cm}$ wide, at the rate of $4.25 \mathrm{~cm} / \mathrm{min}$. The base-case data provided in Table 1 reflects the projected values for a machine of desired production rate. The data have been grouped by production rate and the five cost parameters.

IPEG price estimation results based on the base-case data of Table 1 are presented in Table 2. It is estimated that $6345 \mathrm{~m}^{2}$ of silicon sheet would be produced per machine per year at a cost of $\$ 139,839$, resulting in an add-on price of $\$ 22.04 / \mathrm{m}^{2}$. The composition of AMC in terms of the cost parameters and the corresponding coefficients are given in Table 2. The add-on price breakdown in terms of cost parameter contributions is presented in Table 2. Direct labor is the primary cost driver, contributing $46 \%$ of the add-on price; materials contribute on 1 y $4 \%$. The contribution of equipment cost is $21 \%$ of the add-on price, and the contributions of area and utilities are $15 \%$ and $14 \%$ respectively.

The estimated add-on price of $\$ 22.04 / \mathrm{m}^{2}$ with the projected data is slightly below the LSA Project goal of $\$ 23.3 / \mathrm{m}^{2}$ for the EFG process. If technical development is achieved according to the projections, the EFG process meets the project goals. Because of the inherent uncertainty of such projections, the sensitivity of the add-on price with respect to the production rate and the cost parameters is of interest. The results of the sensitivity analysis are presented below.

\section{A. PRODUCTION RATE}

For this analysis the duty cycle is varied from 0.75 to 0.95 with 0.05 increments, the process yield is varied from 0.80 to 0.95 with 0.05 increments and the growth rate is varied from $2.5 \mathrm{~cm} / \mathrm{min}$ to $5.5 \mathrm{~cm} / \mathrm{min}$ with increments of $0.5 \mathrm{~cm} / \mathrm{min}$. The input data for the DTCY, PRYL and GRCMPM for the base case are $0.90,0.90$ and $4.25 \mathrm{~cm} / \mathrm{min}$ respectively. Figures la through le present results of growth rate vs add-on price for each combination of DTCY and PYKL.

Figure la indicates that with DTCY and PRYL of 0.95 each, the growth rate should be not less than $3.6 \mathrm{~cm} / \mathrm{min}$ in order to achieve the LSA goal. Figure le suggests that for DTCY of 0.75 and PRYL of 0.95 , it is necessary to achieve a growth rate of $4.5 \mathrm{~cm} / \mathrm{min}$ to meet the goal. For the case of 


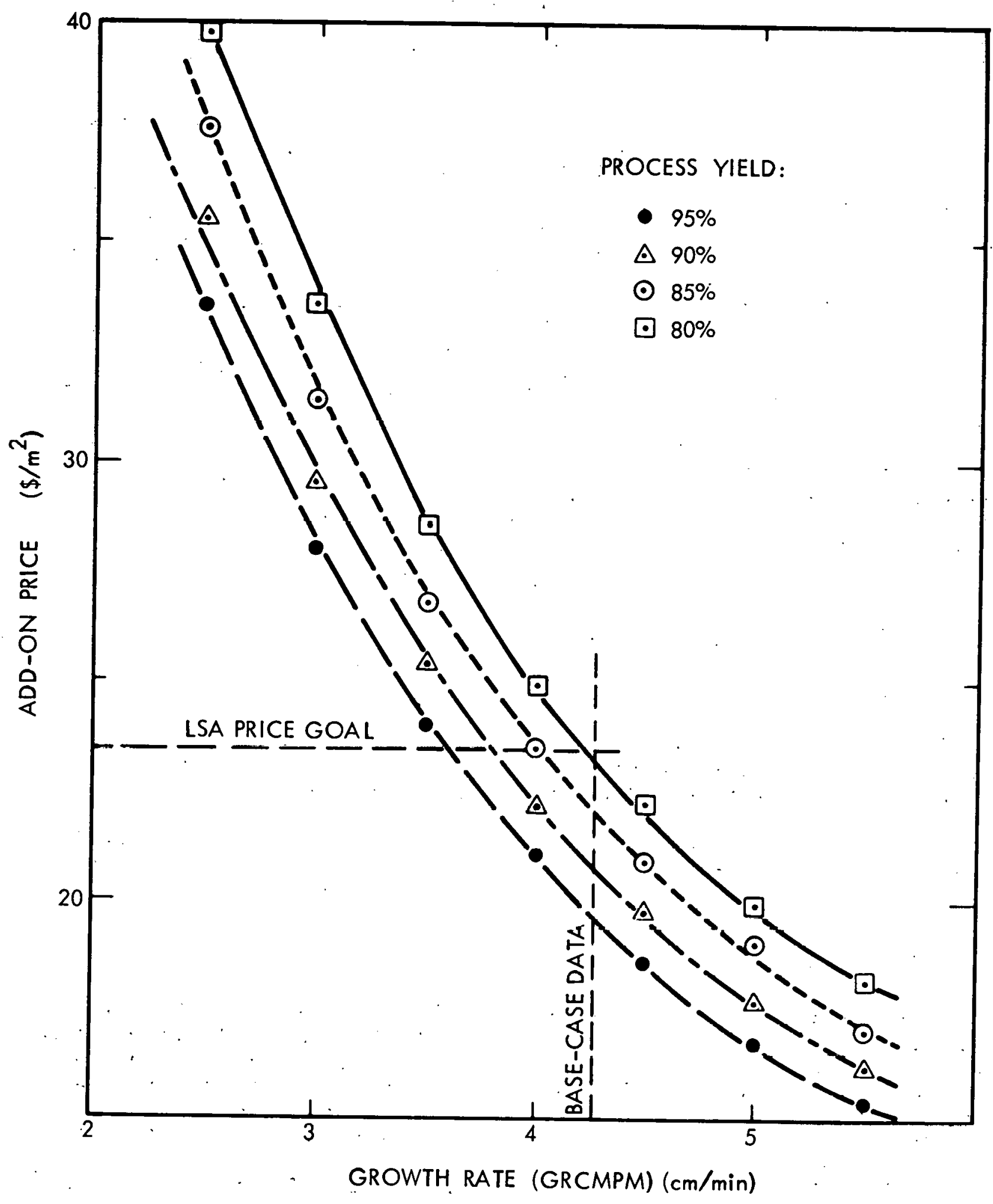

Figure 1a. EFG Process Growth Rate vs Add-on Price for Duty Cycle $=0.95$ 


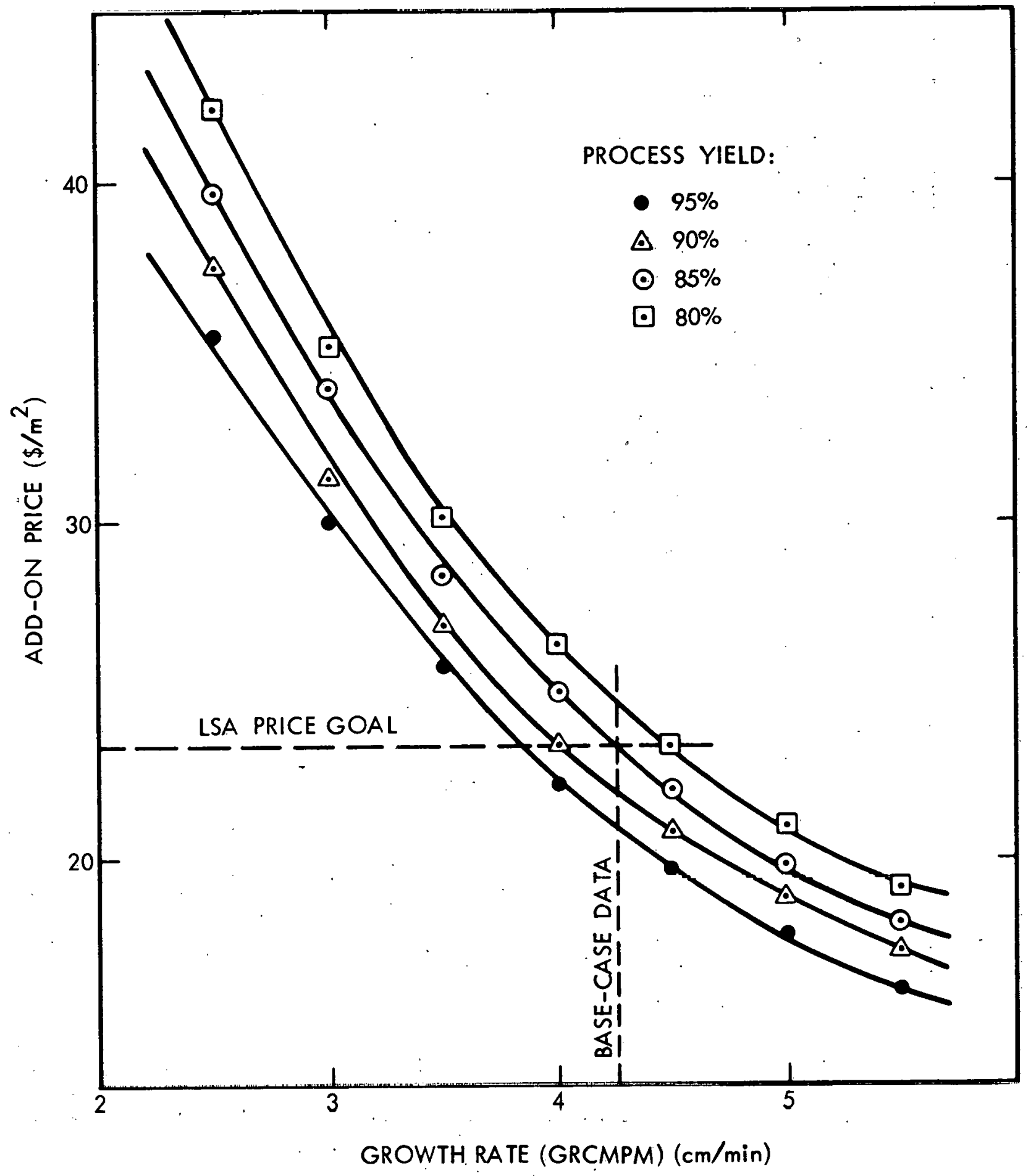

Figure 1b. EFG Process Growth Rate vs Add-on Price for Duty Cycle $=0.90$ 


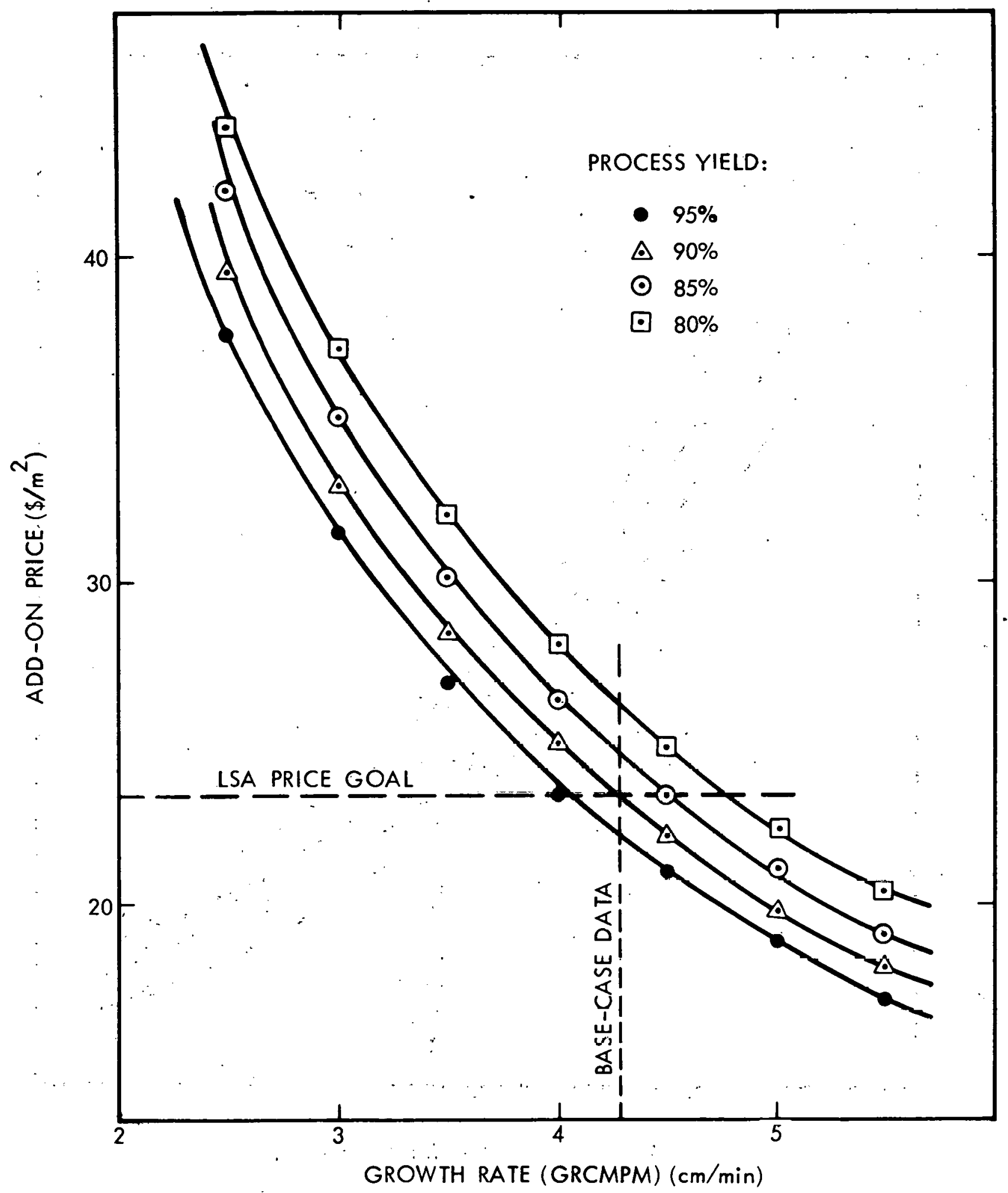

Figure 1c. EFG Process Growth Rate vs Add-on Price for Duty Cycle $=0.85$ 


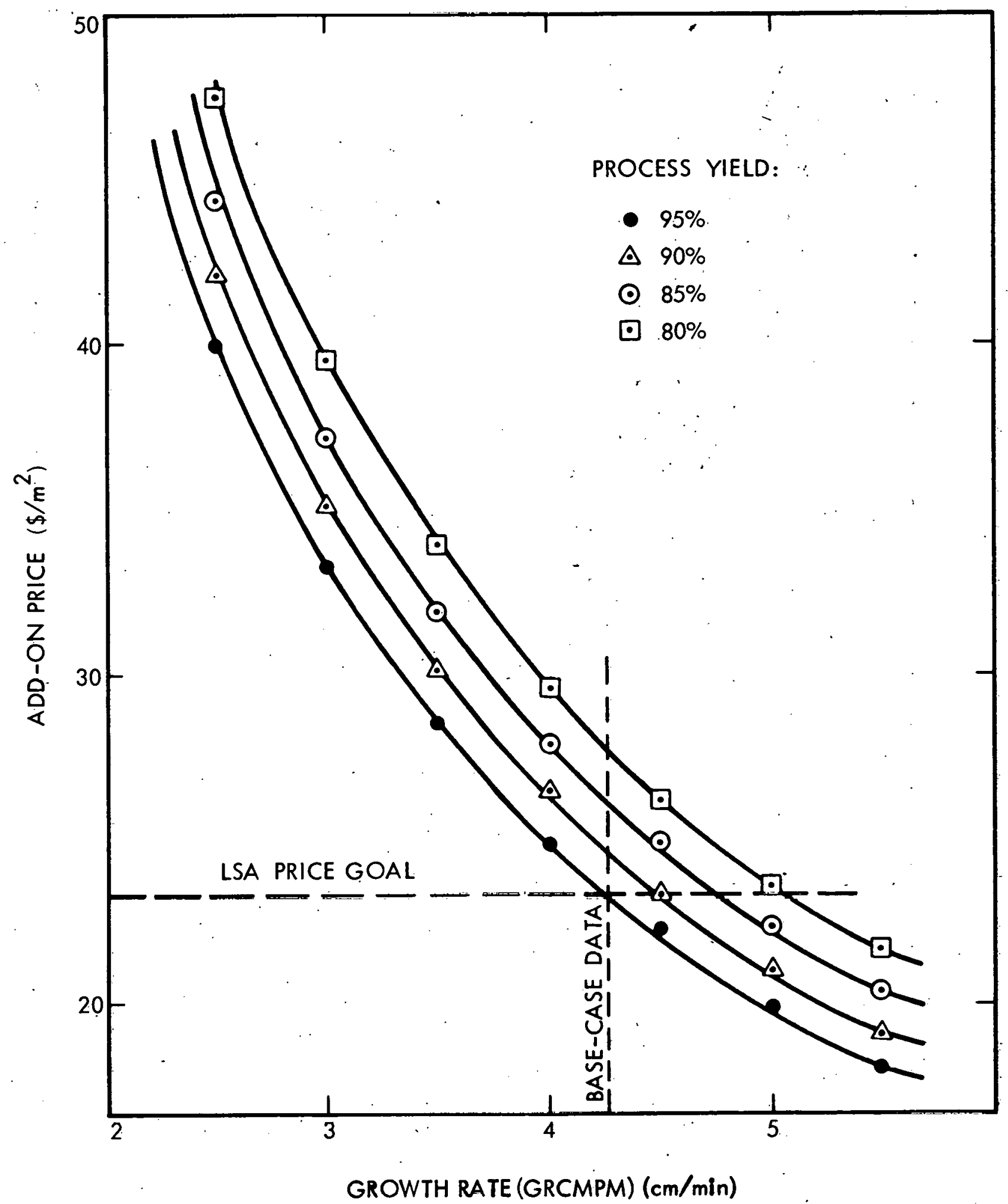

Figure 1d. EFG Process Growth Rate vs Add-on Price for Duty Cycle $=0.80$ 


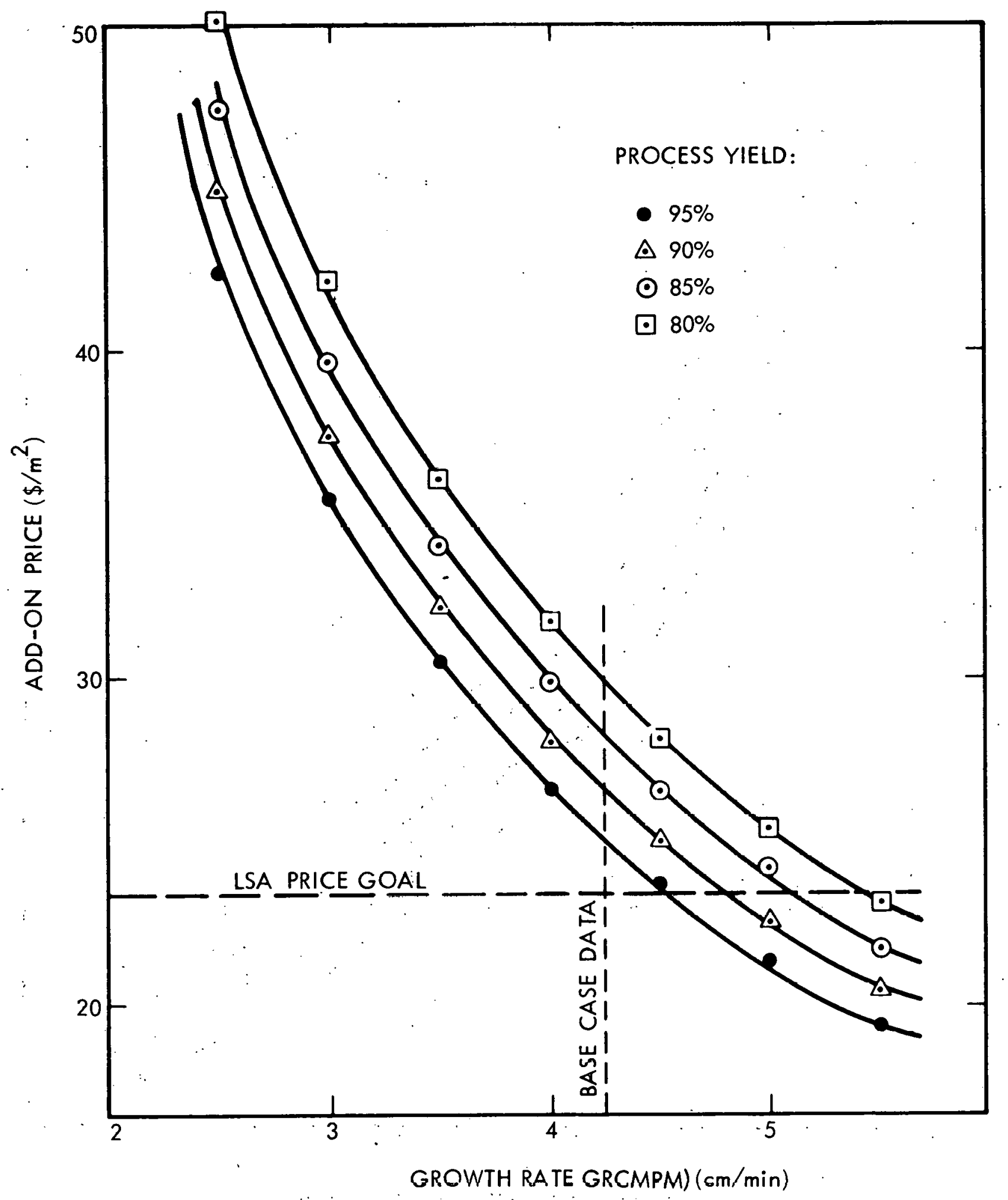

Figure 1e: EFG Process Growth Rate vs Add-on Price for Duty Cycle $=0.75$ 
DTCY $=0.75$ and PRYL $=0.80$, the minimum growth rate should be $5.5 \mathrm{~cm} / \mathrm{min}$. At the current technology level it appears that a growth rate greater than $4.25 \mathrm{~cm} / \mathrm{min}$ would be difficult to achieve.

Growth of three ribbons simultaneously, each $10 \mathrm{~cm}$ wide, at the rate of $3.0 \mathrm{~cm} / \mathrm{min}$ has been demonstrated. For the projected growth rate of $4 \mathrm{~cm} / \mathrm{min}$, the price goal is achieved with DTCY and PRYL 0.90 each (Figure lb).

Therefore, for a growth rate of $4 \mathrm{~cm} / \mathrm{min}$, the product of DTCY and PRYL should be not less than 0.81 . In Figure $1 \mathrm{c}, \mathrm{DTCY}=0.85$ and $\mathrm{PRYL}=0.95$ would just meet the price goal at the growth rate of $4 \mathrm{~cm} / \mathrm{min}$. It is also observed that for DTCY or PYRL less than 0.80 it is not possible to meet the price goal with growth rate of $4 \mathrm{~cm} / \mathrm{min}$ (Figures $1 \mathrm{~d}$ and $1 \mathrm{e}$ ). The analysis suggests an effort to achieve 0.90 for DTCY and PYRL for the growth rate of $4 \mathrm{~cm} / \mathrm{min}$. In this analysis the ribbon width of $10 \mathrm{~cm}$, and four ribbons per furnace, are fixed. The working time per year is assumed to be 320 days (RNLNYR $x$ RNPYR), allowing 45 days for maintenance and repair time. It is possible to modify these data and repeat the sensitivity analysis with respect to the production rate.

\section{B. COST OF EQUIPMENT}

The cost of equipment for the base-case data in Table 1 is $\$ 51,000$ and the lifetime of the equipment is seven years. The cost of equipment is varied by considering the life of equipment to be three, five, seven and 10 years; for each of the assumed lifetimes the cost varies from $\$ 25,000$ to $\$ 65,000$, with increments of $\$ 10,000$. The graph of add-on price vs equipment cost is shown in Figure 2. For equipment of three years' lifetime, cost can be as high as $\$ 45,000$ and still meet the goal. For equipment of seven years' lifetime, the cost can be as high as $\$ 65,000$ and still meet the goal.

\section{AREA, MATERIALS AND UTILITIES COSTS}

The base-case value for area is $200 \mathrm{ft}^{2}$ per machine, contributing $15 \%$ of the add-on price. Area required is varied from $100 \mathrm{ft}^{2}$ to $400 \mathrm{ft}^{2}$. The graph of area vs add-on price is given in Figure 3. The area can be increased to $270 \mathrm{ft}^{2}$ without exceeding the price goal.

The cost of materials for the base case is $\$ 4,796$, contributing only $4 \%$ of the add-on price. The add-on price is least influenced by this parameter. The graph of materials cost vs add-on price is shown in Figure 4. For materials cost as high as $\$ 6,500$, the add-on price is still below the goal price.

The base-case data give $\$ 15,974$ as utilities cost, contributing $14 \%$ to the add-on price. The utilities cost varies from $\$ 5,000$ to $\$ 25,000$; the graph of utility cost vs add-on price is given in Figure 5. It may be observed that the utilities cost can go as high as $\$ 23,000$ without exceeding the goal. 


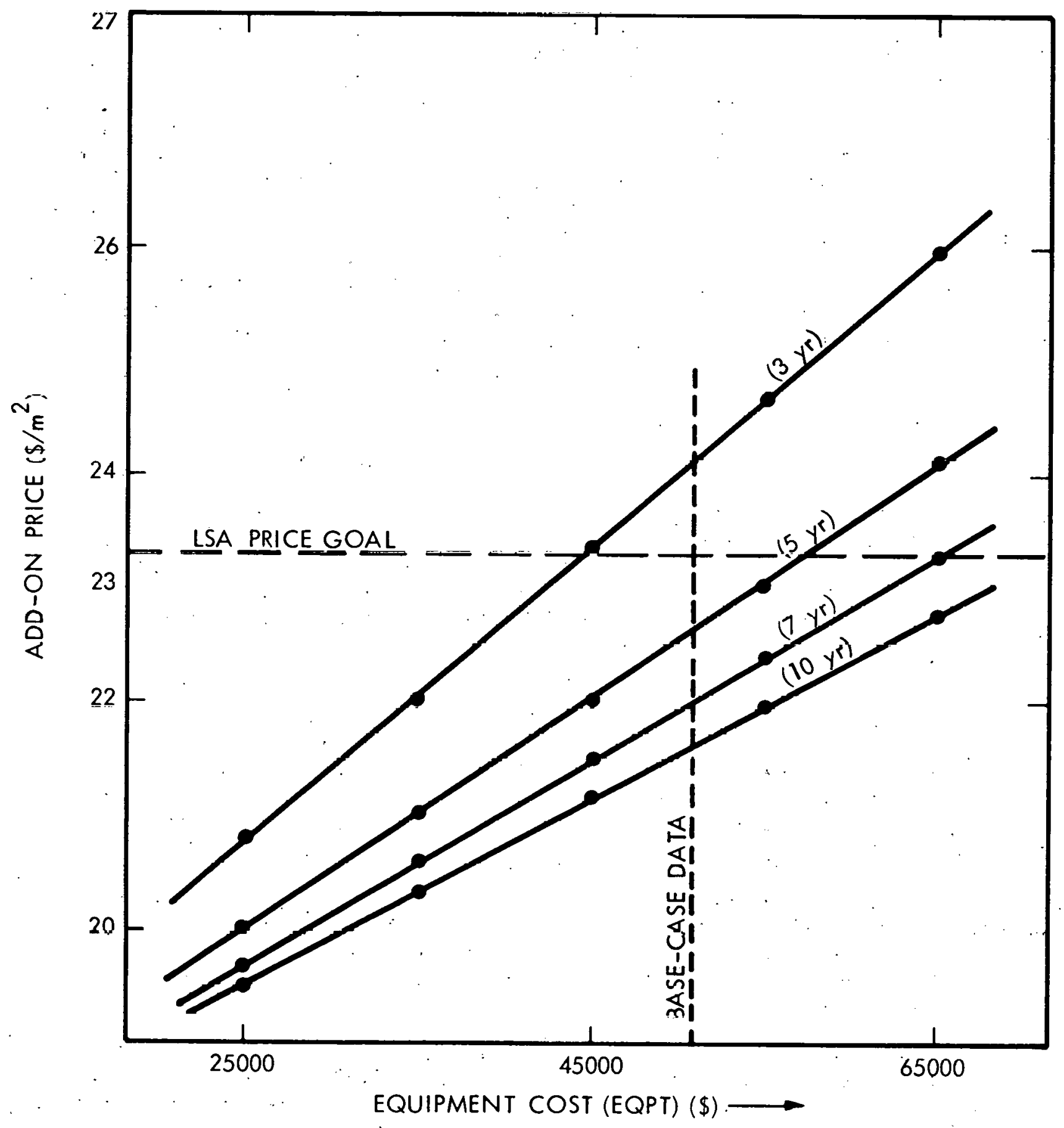

Figure 2. EFG Process Equipment Cost vs Add-on Price 


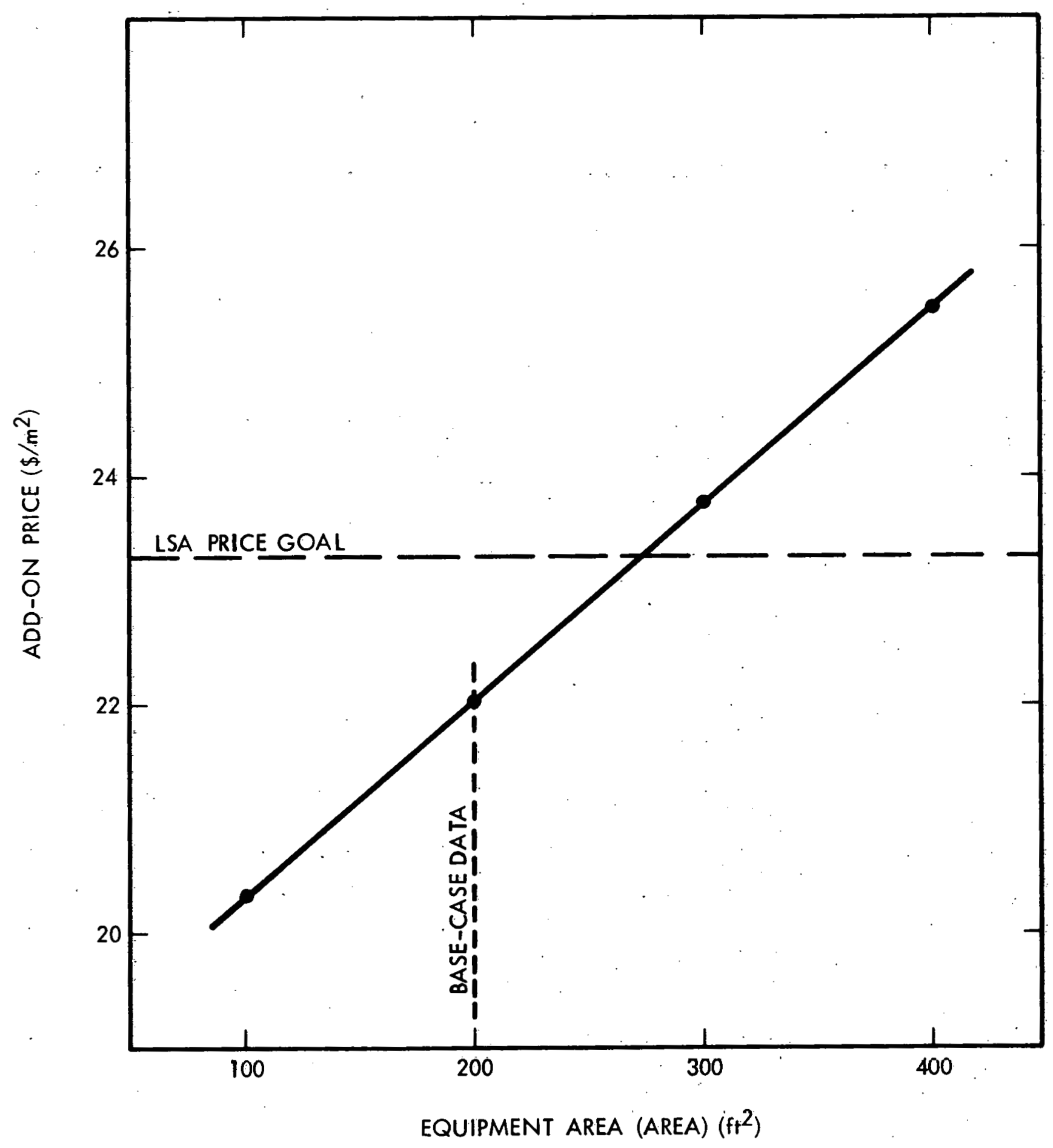

Figure 3. EFG Process Equipment Area vs Add-on Price 


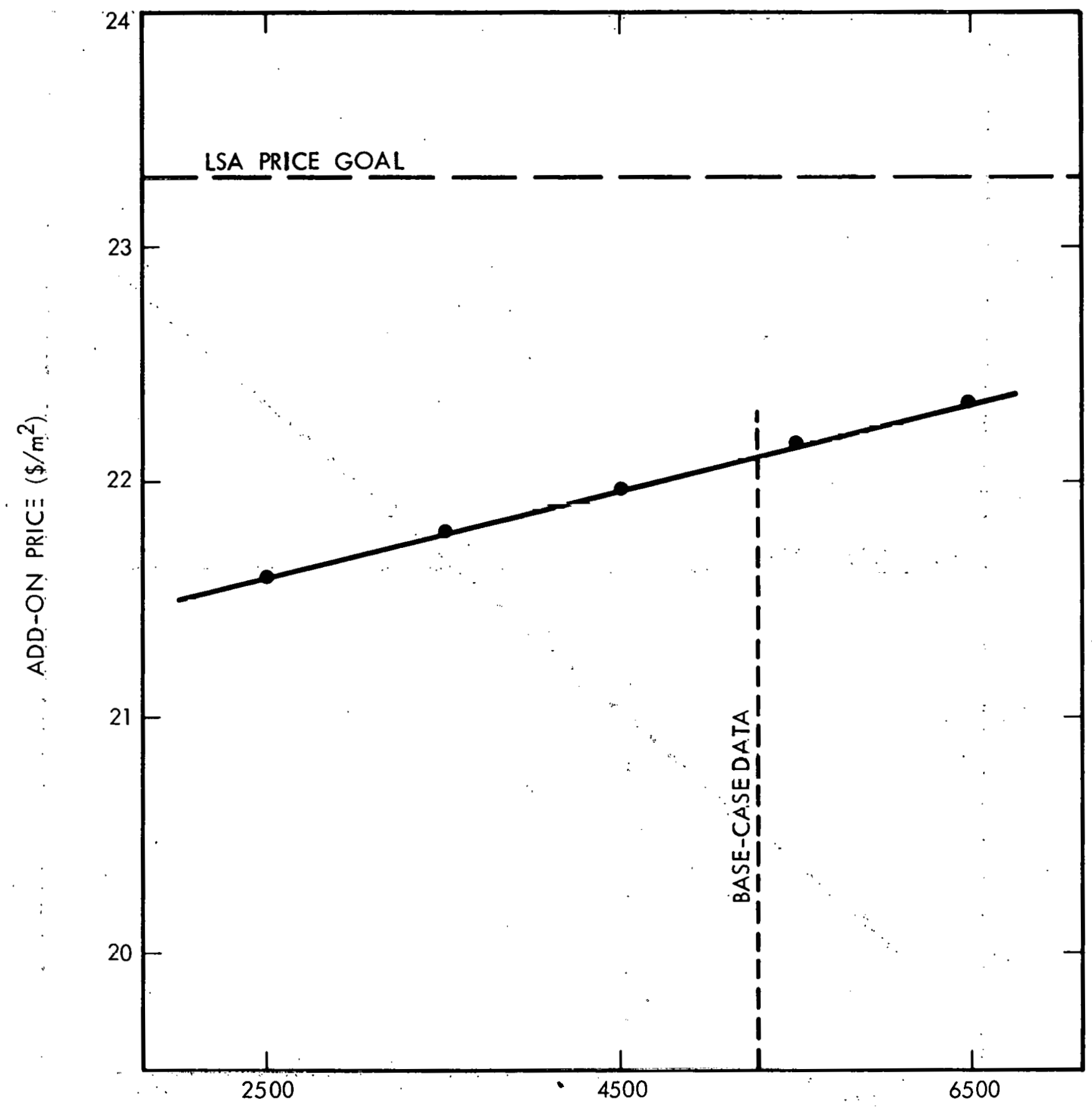

DIRECT MATERIAL COST (MATS) (\$)

Figure 4. EFG Process. Direct Material Cost vs Add-on Price

24 


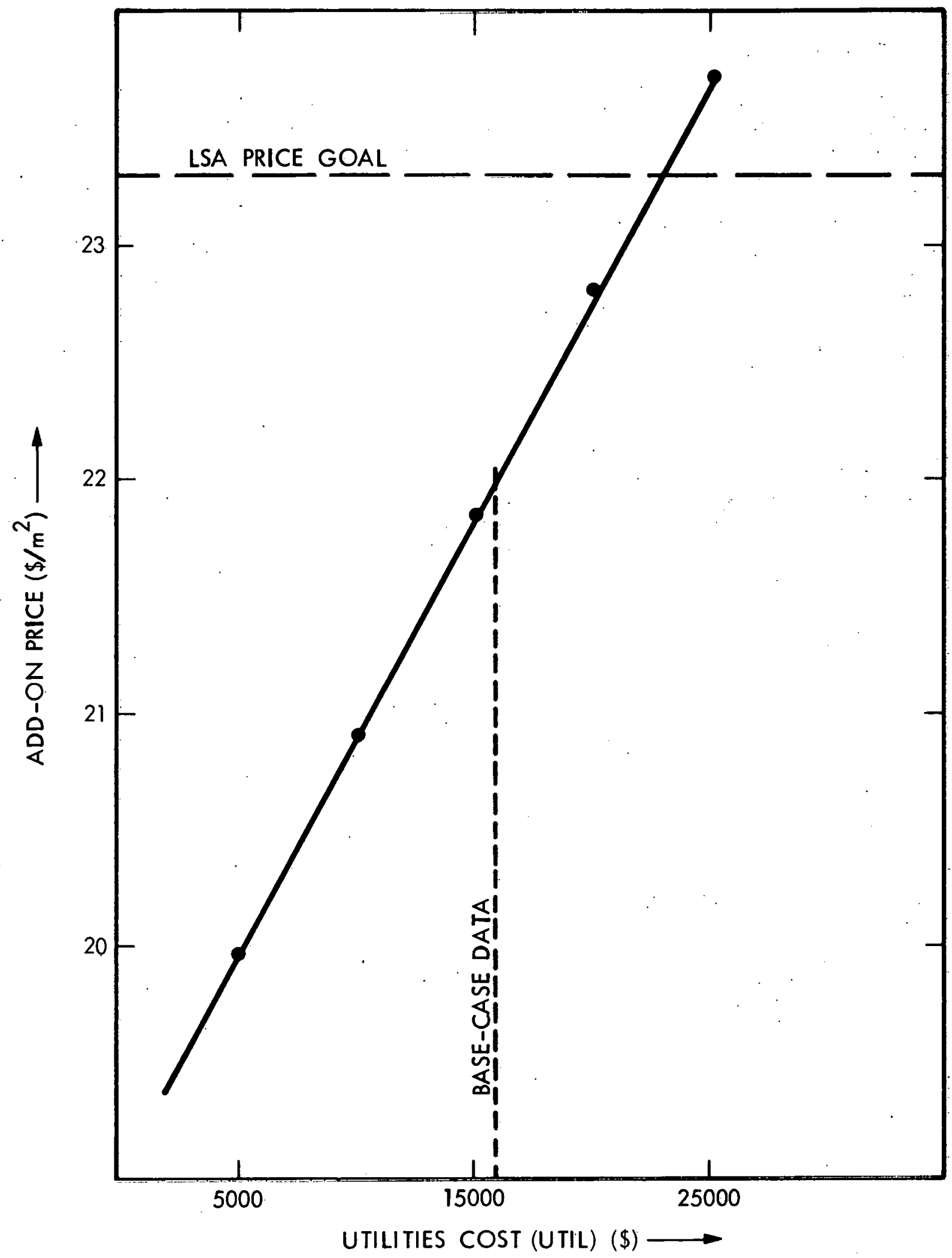

Figure 5. EFG Process Utilities Cost vs Add-on Price 


\section{DIRECT LABOR COST}

The base-case data have shown that direct labor is the primary cost driver, contributing $46 \%$ of the add-on price. The direct 1 abor cost is a function of the labor pay rate and the number of furnaces operated by a single operator. The base case assumes an operator pay rate of $\$ 7 / \mathrm{h}$ (excluding fringe benefits) with one worker operating three furnaces. For the sensitivity analysis, the labor pay rate is varied from $\$ 5 / \mathrm{h}$ to $\$ 11 / \mathrm{h}$ (excluding fringe benefits). The number of furnaces operated by a single operator (FPO) is varied from 1 to 12 for each labor pay rate considered. The graphs of FPO vs add-on price are shown in Figure 6. It may be observed that the cost of direct labor is reduced considerably when FPO is increased from 1 to 6. The incremental decrease in the add-on price for FPo greater than 6 is negligible, as the curves are asymptotic. 'This suggests that efforts to automate the equipment in order to increase FPO should be 1 imited to achieve FPO between 3 and 6 . There is not much control over the labor pay rate, which is governed by external factors. Automation reduces the skills required and hence reduces the labor cost. For FPO of 6 the price goal is met with a labor pay rate as high as $\$ 11 / \mathrm{h}$. It is also shown that the price goal is not met with FPO of 1 and labor pay rate as low as $\$ 5 / \mathrm{h}$. 


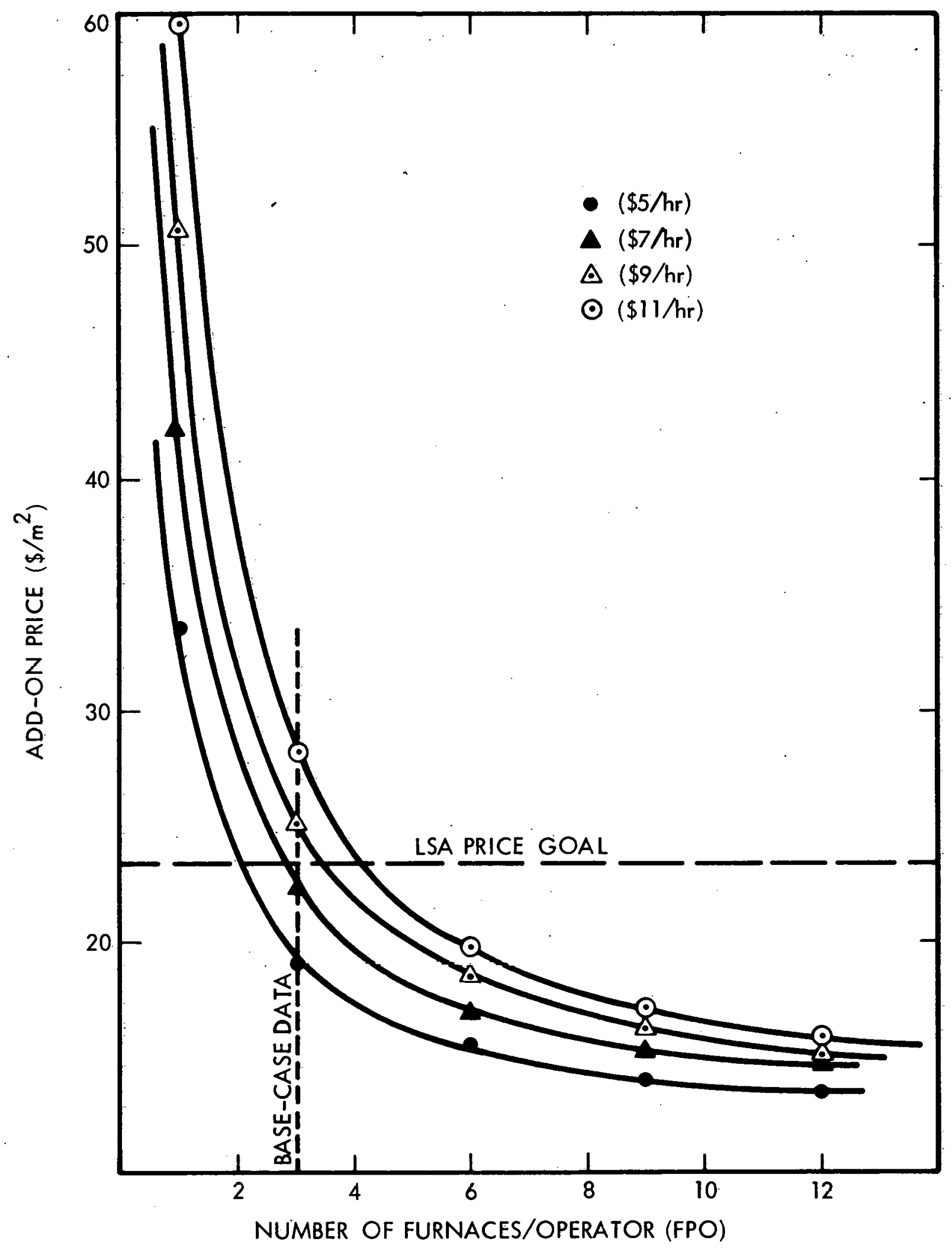

Figure 6. EFG Process Direct Labor Cost vs Add-on Price 
THIS PAGE

\section{WAS INTENTIONALLY LEFT BLANK}




\section{SECTION $V$}

\section{CONCLUSTONS}

The projected input data set for economic analysis by IPEG indicates that the add-on price goals can be met if all of the assumptions implied in the input data set are achieved. The ribbon-growth equipment is expected to operate on a continuous basis with melt replenishment, growing four ribbons simultaneously, each $10 \mathrm{~cm}$ wide, at the rate of $4.25 \mathrm{~cm} / \mathrm{min}$ with duty cycle and process yield of $90 \%$ each. Each of these parameters, such as number of ribbons, ribbon width, and growth rate, has been shown to achieve the desired values independently. However, all of these parameter values have not been achieved simultaneously. Efforts are being directed toward achieving this in order to attain Technical Readiness by 1982 .

The add-on price breakdown indicates that the cost of direct labor is the primary cost driver, contributing $46 \%$ of the price; the cost of materials is the weakest cost driver, contributing only $4 \%$ of the price. Efforts should therefore be directed to reduce the labor requirement by increasing automation. The sensitivity analysis indicates that it does not pay to increase the number of furnaces tended by an operator to more than six.

The SAIPEG analysis is helpful in understanding the relative importance of the cost parameters and the add-on price sensitivity to each of them. This knowledge would be useful in planning efforts to improve the most sensitive cost parameters. The SAIPEG analysis should be performed on a continuous basis when results dictate modification of base-case input data. 
THIS PAGE

\section{WAS INTENTIONALLY LEFT BLANK}




\section{REFERENCES}

(1) Aster, R. W., Price Allocation Guidelines, JPL Document 5101-68, Revision A (JPL Publication 80-51, DOE/JPL-1012-47), Jet Propulsion Laboratory, Pasadena, California, January 15, 1980.

(2) Nagy, S., "Silicon Sheet Cost and Technology Project," Proceedings of the 8th Project Integration Meeting, JPL Internal Document 5101-52, pp. 3-13 to 3-26, Jet Propulsion Laboratory, Pasadena, California, December 1977.

(3) Aster, R.W., and Chamberlain, R.G., Interim Price Estimation Guidelines: a Precursor and an Adjunct to SAMIS III, Version 1, JPL Internal Document.5101-33, Jet Propulsion Laboratory, Pasadena, California, September 10, 1977.

(4) Chamberlain, R.G., and Aster, R.W., Solar Array Manufacturing Industry Costing Standards (SAMICS) Usage Update No. 1, JPL Internal Document 5101-59, Jet Propulsion Laboratory, Pasadena, California, February 1 , 1978.

(5) Firnett, P.J., Standard Assembly-Line Manufacturing Industry Simulation (SAMIS) Computer Program User's Guide, Release 3, JPL Interna1 Document 5101-60, Revision B, Jet Propulsion Laboratory, Pasadena, California, April 21, 1980.

(6) Aster, R.W., "IPEG2: Improved Price Estimation Guidelines," Proceedings of the 14th Project Integration Meeting, JPL Document 5101-142 (JPL Publication 80-21, DOE/JPL-1012-42), pp. 355-357, Jet Propulsion Laboratory, Pasadena, California, December 1979. 